\title{
Growth rate and acid-base balance in turkeys fed a silage-containing diet modified by different dietary cation-anion difference
}

\author{
KAMIL GRUSZCZYŃSKI, WACŁAW STROBEL*, MARTA WÓJCIK**, \\ URSZULA KOSIOR-KORZECKA**, JOANNA WESSELY-SZPONDER**, \\ RYSZARD BOBOWIEC**
}

\author{
Animal Pharma Lublin, Al. Spółdzielczości Pracy 103, 20-147 Lublin, Poland \\ *Institute of Agrophysics, Polish Academy of Science, Doświadczalna 4, 20-290 Lublin, Poland \\ **Sub-faculty of Preclinical Veterinary Sciences, Department of Pathophysiology, Faculty of Veterinary Medicine, \\ University of Life Sciences in Lublin, Akademicka 12, 20-033 Lublin, Poland
}

Gruszczyński K., Strobel W., Wójcik M., Kosior-Korzecka U., Wessely-Szponder J., Bobowiec R. Growth rate and acid-base balance in turkeys fed a silage-containing diet modified by different dietary cation-anion difference

Summary

The aim of the study was to find the responses of acid-base parameters and performance parameters of turkeys to a corn silage (CS) diet with different values of the dietary cation-anion difference (DCAD). The turkeys were fed as follows: group A (control) - standard diet (SD) (60\%) plus CS (40\%); group B - SD (60\%), CS (40\%) plus $240 \mathrm{~g}$ of $\mathrm{CaCl}_{2}$ per100 kg of diet; group C - SD (60\%), CS (40\%) plus $480 \mathrm{~g}$ of $\mathrm{CaCl}_{2}$ per $100 \mathrm{~kg}$ of diet; group D - SD (60\%), CS (40\%) plus $240 \mathrm{~g}$ of $\mathrm{NaHCO}_{3}$ per $100 \mathrm{~kg}$ of diet; group $\mathrm{E}$ - SD (60\%), CS (40\%) plus $480 \mathrm{~g} \mathrm{NaHCO}$ per $100 \mathrm{~kg}$ of diet. The addition of the smaller amount of $\mathrm{CaCl}_{2}$ reduced $\mathrm{DCAD}$, which ranged between $49.75 \pm 6.29 \mathrm{mEq} / \mathrm{kg} \mathrm{DM}$ and $93.56 \pm 3.34 \mathrm{mEq} / \mathrm{kg} \mathrm{DM}$. An increased content of $\mathrm{CaCl}$, led to high, negative values of DCAD. $\mathrm{NaHCO}_{3}$ supplemented in both doses resulted in a significant elevation of DCAD. The addition of CS to the SD led to a lower body weight in comparison to that in the B, C, D and E groups. Forage acidification and alkalization improves body weight gain (BWG) at every stage of feeding. Compared to the control group, the anion gap was insignificantly lower in birds exposed to the acidic diet, and was comparable to the decrease in $\mathrm{HCO}_{3}^{-}$. Conversely, the addition of $\mathrm{NaHCO}_{3}$ to the diet led to a marked elevation in $\mathrm{HCO}_{3}^{-}$to $29.63 \pm 0.4 \mathrm{mEq} / \mathrm{L}$ in group $\mathrm{D}$ and to $30.3 \pm 0.69 \mathrm{mEq} / \mathrm{l}$ in group $\mathrm{E}$. In conclusion, a change in DCAD during the feeding of forage containing CS exerts stimulatory effects on productive parameters of turkeys.

Keywords: anion gap, body mass gain, corn silage, dietary cation-anion difference, turkey

One of alternative foods for broiler turkeys might be inexpensive corn silage added to the typical formula. Although the addition of corn silage to the daily meal is well accepted by turkeys, the growth rate, according to our observations, is diminished. So far, very little attention has been paid to the manipulation of DCAD in growing turkeys. Since one of the causes of the growth rate suppression by silage may be a deviation in DCAD, we sought to determine whether lowering or increasing these values may improve the performance of growing young turkeys. It is known that in other species a higher DCAD stimulates the apparent digestibility coefficient (ADC) of protein and dry matter, but concomitantly the maintenance energy expenditure (MEm) is also higher $(20,22)$. At least in some spe- cies, a lower acidic content and high potassium in the diet enhance both bone accretion and bone health. Seemingly, Kim et al. (14) discovered that, in opposition to chloride, cation supplementation alleviates the lysine-arginine antagonism in chicks.

Hitherto, our attention in broilers has been focused on the specific effects of cations and anions in the diet $(1,13,17,23)$. Our aim was to determine the responses of turkeys to a corn silage diet with different values of DCAD and to draw attention to the possible usefulness of this kind of ingredient in turkey farming. Moreover, since the dietary intake has been shown to influence the acid-base balance (ABB), our studies were aimed at clarifying the response of ABB-parameters in turkeys fed a corn silage diet with different DCAD. To obtain 
a clear view of the consequences of the manipulation of DCAD, we also compared performance parameters in all of the studied groups of turkeys.

\section{Material and methods}

Birds husbandry. One hundred and eight 28-day-old female turkeys (BUT-6) were used in our experiment. The birds were obtained from a commercial hatchery, and, until the experiment, they were fed a standard diet appropriate for their age. The experiment was carried out in floor pens $\left(2.5 \times 2.5 \mathrm{~m}^{2}\right)$ arranged by blocks at a turkey farm in Petryłów, Poland. At the start of the experiment, the birds were weighed individually and divided randomly into 6 groups of 18 birds each, assigned to 6 pens (the average weight per cage was similar). The birds were housed in an environmentally controlled room according to the standard turkey management practice. The trial started in the $4^{\text {th }}$ week of the birds' life and lasted until the $14^{\text {th }}$ week. During this period, the birds were provided with a 3-phase feeding programme: grower I was conducted for 4 weeks, grower II for 4 weeks, and finisher for 2 weeks. All experimental procedures were approved by the Local Ethics Committee of Animal Care at the University of Life Sciences in Lublin (No 18/2014).

Diets. The turkeys in particular groups were fed as follows: group $\mathrm{A}(\mathrm{n}=18)$ (control) - standard diet $(60 \%)$ plus corn silage (40\%); group B ( $\mathrm{n}=18)$ - standard diet $(60 \%)$, corn silage (40\%) plus $240 \mathrm{~g}$ of $\mathrm{CaCl}_{2}$ per $100 \mathrm{~kg}$ of diet; group $\mathrm{C}(\mathrm{n}=18)-$ standard diet $(60 \%)$, corn silage $(40 \%)$ plus $480 \mathrm{~g}$ of $\mathrm{CaCl}_{2}$ per $100 \mathrm{~kg}$ of diet; group D ( $\left.=18\right)$ - standard diet $(60 \%)$, corn silage $(40 \%)$ plus $240 \mathrm{~g}$ of $\mathrm{NaHCO}_{3}$ per $100 \mathrm{~kg}$ of diet; group $\mathrm{E}(\mathrm{n}=18)$ - standard diet $(60 \%)$, corn silage $(40 \%)$ plus $480 \mathrm{~g} \mathrm{NaHCO}_{3}$ per $100 \mathrm{~kg}$ of diet. In each group, minced corn silage was mixed with the standard diet to produce a homogenous mass. The composition of the standard diet and corn silage is given in Table 1 and Table 2. Feed was offered for ad libitum intake. Drinking water was continuously supplied.

Performance measurements. Individual bird weights were measured weekly and pen feed residues were determined at the end of each feeding period (grower I, grower II and finisher), to estimate average BW, BWG for each pen (8).

Blood analysis. Before the experiment and at weeks 5 and 10 , venous blood samples were collected into heparinized $\left(50 \mathrm{IU} / \mathrm{mL}^{-1}\right)$ monovette syringes by a puncture of the wing vein (branchial vein). Blood was drawn directly from the syringes into a blood gas/electrolyte analyzer (ABL80 Flex (Radiometer, Copenhagen) for an immediate analysis of $\mathrm{pCO}_{2}$, partial pressure of oxygen $\left(\mathrm{pO}_{2}\right), \mathrm{pH}$, and electrolytes $\left(\mathrm{Na}^{+}, \mathrm{K}^{+}, \mathrm{Ca}^{+}, \mathrm{HCO}^{-}\right.$, and $\left.\mathrm{Cl}^{-}\right)$. The $\mathrm{pH}, \mathrm{pCO}_{2}, \mathrm{pO}_{2}$, and $\mathrm{HCO}_{3}$ values were corrected to reflect a body temperature of $41.5^{\circ} \mathrm{C}$. The anion gap (AG) was calculated by the formula $\mathrm{AG}=\left(\mathrm{Na}^{+}+\mathrm{K}^{+}\right)-\left(\mathrm{Cl}^{-}+\mathrm{HCO}_{3}^{-}\right)(4)$.

Analytical procedures. To obtain a constant dry weight of diet samples, each of them was dried at $105^{\circ} \mathrm{C}$. In the next step, for $0.5 \mathrm{~g}$ of every sample, $18 \mathrm{ml}$ of digested mixture $(70 \%$ perchloric acid : $60 \%$ nitric acid $[5: 1 \mathrm{v} / \mathrm{v}])$ was added. After a two-phase mineralization process (phase I: $180^{\circ} \mathrm{C} / 20 \mathrm{~min}$, phase II: $220^{\circ} \mathrm{C} / 90 \mathrm{~min}$ ), the samples were
Tab 1. Ingredients and composition of the standard diet for turkey broilers according to the manufacturer's specification (De Heus, Animal Feed Industry, Lęczyca, Poland)

\begin{tabular}{|l|c|c|c|}
\hline \multicolumn{1}{|c|}{ Ingredients (g/kg diet) } & Grower I & Grower II & Finisher \\
\hline Soybean oil (GM0) & 19.85 & 30.38 & 29.83 \\
\hline Yellow corn & 200.00 & 200.00 & 200.00 \\
\hline Dicalcium phosphate & 14.41 & 12.52 & 10.64 \\
\hline Coarse chalk & - & 9.71 & 7.72 \\
\hline Fine chalk & 13.01 & - & - \\
\hline Fish Meal & 20.00 & - & - \\
\hline Wheat & 305.91 & 337.32 & 373.73 \\
\hline Monensin ionophore 1+2 & 20.00 & - & - \\
\hline Monensin ionophore 3+4 & - & 20.00 & 20.00 \\
\hline Soybean meal & 366.82 & 360.07 & 258.08 \\
\hline Canola hulls & 40.00 & 30.00 & 60.00 \\
\hline Crude protein \% & 25.75 & 24.00 & 20.80 \\
\hline Lipids \% & 4.26 & 5.10 & 5.40 \\
\hline Crude fiber \% & 2.89 & 2.81 & 2.96 \\
\hline Ash \% & 7.27 & 6.59 & 5.86 \\
\hline Lysine \% & 1.64 & 1.49 & 1.26 \\
\hline Methionine + cysteine \% & 1.09 & 0.95 & 0.88 \\
\hline Methionine \% & 0.69 & 0.57 & 0.53 \\
\hline Threonine \% & 0.97 & 0.91 & 0.79 \\
\hline Tryptophan \% & 0.31 & 0.29 & 0.25 \\
\hline Calcium \% & 1.20 & 1.05 & 0.94 \\
\hline Sodium \% & 0.16 & 0.13 & 0.13 \\
\hline Vit. B1 mg/kg & 4.96 & 3.80 & 3.29 \\
\hline Vit. B12 \%g/kg & 31.25 & 20.00 & 20.00 \\
\hline Vit. B2 mg/kg & 12.35 & 8.58 & 8.27 \\
\hline Vit. B6 mg/kg & 6.39 & 5.23 & 4.74 \\
\hline Vit. D3 IE/kg & 3000.00 & 3000.00 \\
\hline Vit. E mg/kg & 35.00 & 35.61 \\
\hline
\end{tabular}

transferred to a calibrated tube, and the volume was brought up to $25 \mathrm{ml}$ with deionised water (28). From each kind of diet, 3 samples were analysed.

Diet ion content. For the analysis of the diet ion content $(\mathrm{Na}, \mathrm{Ca}, \mathrm{K}, \mathrm{Mg}$ and S), ICP-OES (Inductively Coupled Plasma Optical Emission Spectrometry) equipped with a charge injection device (CID) detector was used (15). The control of the spectrometer was provided by a PC-based iTEVA software. The following instrumental parameters were set: RF generator
Tab. 2. Ingredients of corn silage for turkey broilers

\begin{tabular}{|l|c|}
\hline \multicolumn{1}{|c|}{ Ingredients } & Corn silage \\
\hline Crude protein \% & 8.6 \\
\hline Carbohydrates \% & 72.0 \\
\hline Crude fiber \% & 42.0 \\
Ash \% & 3.0 \\
Cellulose \% & 22.0 \\
Lignin \% & 4.0 \\
Calcium \% & 0.33 \\
\hline Phosphorous \% & 0.28 \\
\hline
\end{tabular}

Explanations: Daily rations amounted to $2 \mathrm{~kg}$ of grower I plus CS, $5 \mathrm{~kg}$ of grower II plus CS, and $5 \mathrm{~kg}$ of finisher plus CS. The proportion of the mixture is given in the material and methods chapter 
power of $1150 \mathrm{~W}, \mathrm{RF}$ generator frequency of $27.12 \mathrm{MHz}$, coolant gas flow rate of $16 \mathrm{~L} / \mathrm{min}$, carrier gas flow rate of $0.65 \mathrm{~L} / \mathrm{min}$, auxiliary gas at $0.4 \mathrm{~L} / \mathrm{min}$, max. integration times of $15 \mathrm{~s}$, pump rate of $50 \mathrm{rpm}$, axial viewing configuration, 3 replicates, flush time of $20 \mathrm{~s}$. The multi-element stock solution (Inorganic Ventures) contained ${ }^{40} \mathrm{Ca},{ }^{30} \mathrm{~K}$, ${ }^{24} \mathrm{Mg},{ }^{23} \mathrm{Na},{ }^{32} \mathrm{~S},{ }^{31} \mathrm{P}$, in $2 \% \mathrm{HNO}_{3}-1000.00 \mathrm{mg} / \mathrm{L}(\mathrm{ppm})$ (Analityk, Warsaw, Poland).

The chloride content in the diet was measured by the direct potentiometric method with a liquid membrane for a selective chloride ion electrode. Samples of $0.5 \mathrm{ml}$ were mixed with $4.5 \mathrm{ml}$ of deionised water, and $100 \mu 1$ of ISA (ionic strength adjuster - $5 \mathrm{M} \mathrm{NaNO}_{3}$ ) was added to adjust the ionic strength of samples. Two standard chloride solutions with concentrations of $5 \mathrm{mg} \cdot \mathrm{L}^{-1}$ and $10 \mathrm{mg} \cdot \mathrm{L}^{-1}$ were used to calibrate the measuring device (Orion 920A digital ionanalyzer; Orion Research Inc., Boston, USA). The dietary cation-anion difference was calculated from the formula $\operatorname{DCAD}(\mathrm{mEq} / \mathrm{kg} \mathrm{DM})=(\mathrm{Na}+\mathrm{Ca}+\mathrm{Mg}+\mathrm{K})-(\mathrm{S}+\mathrm{Cl})(28)$.

Ileal digesta viscosity. At the end of the experiment, during the non-fed stage, the birds were humanely killed by cervical dislocation to collect duodenal and ileal contents for the determination of digesta viscosity. A homogeneous mixture of duodenal and ileum digesta was placed in two Eppendorf tubes $(1.5 \mathrm{ml})$. The tubes were centrifuged at $3000 \mathrm{~g}$ for $45 \mathrm{~min}$ to separate feed particles from the liquid phase. Supernatants $(0.5 \mathrm{ml})$ from each tube were taken, and the viscosity was measured in a rotary Bohlin Instruments rheomether maintained at $41^{\circ} \mathrm{C}$. Two readings were taken from each tube and expressed as milliPascal seconds (mPars) $(11,24)$.

Statistical analysis. The values were compared using Microsoft Excel and the STATISTICA.PL analysis software, and presented as a mean and standard deviation $(\overline{\mathrm{x}} \pm \mathrm{SD})$. Comparisons between the control and each experimental result were performed by the ANOVA test. A significance value of $\mathrm{P} \leq 0.05$ was used to distinguish significant differences between the results obtained.

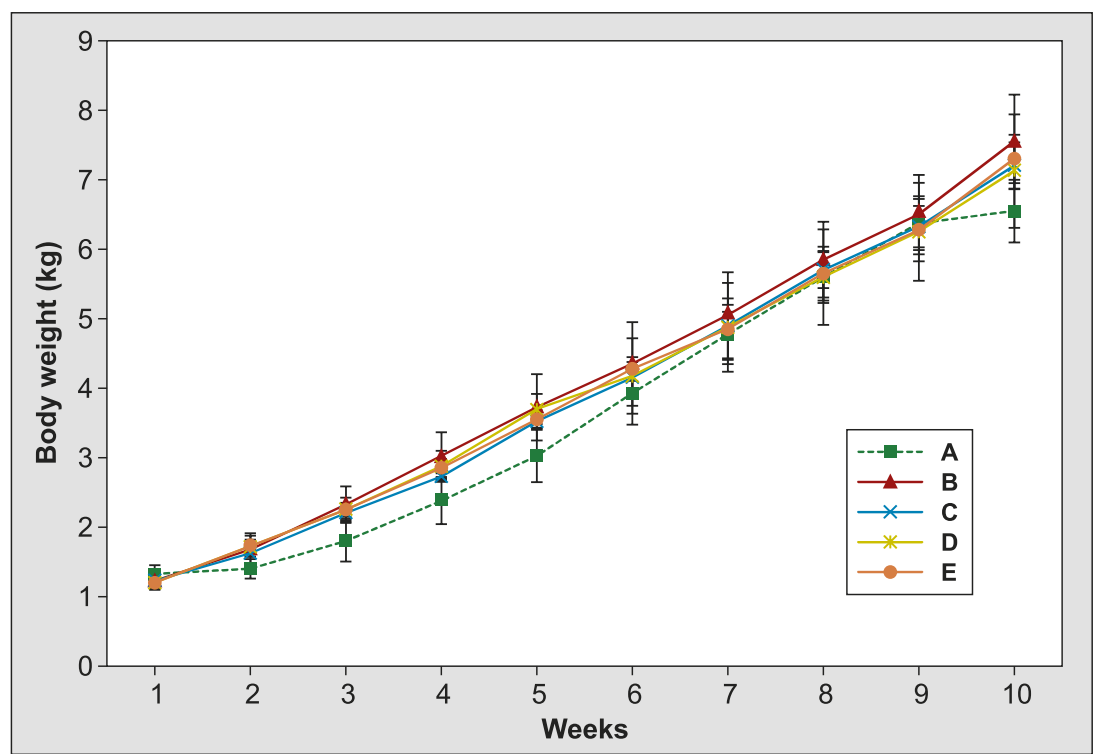

Fig. 1. Time-course of body weight changes as influenced by corn silage and different dietary cation-anion difference
Tab. 3. Values of dietary cation-anion difference obtained in control and experimental turkeys $(\bar{x} \pm \mathrm{SD})$

\begin{tabular}{|c|c|c|c|}
\hline $\begin{array}{c}\text { Control and } \\
\text { experimental } \\
\text { groups }\end{array}$ & $\begin{array}{c}\text { Grower I } \\
\mathrm{mEq} / \mathrm{kg} \mathrm{DM}\end{array}$ & $\begin{array}{c}\text { Grower II } \\
\mathrm{mEq} / \mathrm{kg} \mathrm{DM}\end{array}$ & $\begin{array}{c}\text { Finisher } \\
\mathrm{mEq} / \mathrm{kg} \text { DM }\end{array}$ \\
\hline A & $125.40 \pm 28.4$ & $188.34 \pm 25.61$ & $142.46 \pm 42.39$ \\
B & $49.75 \pm 6.29^{*}$ & $67.90 \pm 18.37^{*}$ & $93.56 \pm 3.34^{*}$ \\
\hline C & $-113.76 \pm 9.48^{*}$ & $-108.35 \pm 11.81^{*}$ & $-117.70 \pm 54.38^{*}$ \\
D & $266.77 \pm 19.16^{*}$ & $259.97 \pm 8.58$ & $224.02 \pm 29.13^{*}$ \\
\hline E & $307.48 \pm 54.96^{*}$ & $308.20 \pm 49.74^{*}$ & $338.97 \pm 25.93^{*}$ \\
\hline
\end{tabular}

Explanations: Values are obtained from replicates of analysing ions used to DCAD calculation; *significant differences (at $\mathrm{P} \leq 0.05)$ vs. DCAD value obtained in corn silage-fed turkeys (group A)

\section{Results and discussion}

The values of the control and experimental DCAD obtained in grower I, grower II and finisher rations are summarised in Table 3. Under control conditions, all DCAD values were positive and reached the maximum $(188.34 \pm 25.61 \mathrm{mEq} / \mathrm{kg} \mathrm{DM})$ in grower II. The addition of the smaller amount of $\mathrm{CaCl}_{2}$ to the diet lowered DCAD to $49.75 \pm 6.29 \mathrm{mEq} / \mathrm{kg} \mathrm{DM}$ and $93.56 \pm 3.34$ $\mathrm{mEq} / \mathrm{kg} \mathrm{DM}$ in grower I and the finisher, respectively. An increased content of $\mathrm{CaCl}_{2}$ led to high, negative values of DCAD in each diet used in the experiment. $\mathrm{NaHCO}_{3}$ supplemented at both 240 and $480 \mathrm{~g} / 100 \mathrm{~kg}$ of diet resulted in a significant elevation of DCAD irrespective of the kind of diet, with the highest $338.97 \pm 25.93 \mathrm{mEq} / \mathrm{kg} \mathrm{DM}$ in the finisher.

As shown in Fig. 1, the addition of corn silage to the standard diet leads to a lower body weight in comparison to the other groups. This lower BW was maintained until the $7^{\text {th }}$ week of growing. During the last week of feeding, BW increased only slightly, from $6.37 \pm 0.38 \mathrm{~kg} / \mathrm{bird}$ to $6.55 \pm 0.54 \mathrm{~kg} / \mathrm{bird}$, which was different from the other groups. Beginning in the $3^{\text {rd }}$ week of our experiment, the highest, linear increase in BW was observed in turkeys exposed to $\mathrm{CaCl}_{2}$ at $240 \mathrm{~g} / 100 \mathrm{~kg}$ of diet. Under such conditions, BW reached its highest value of $7.55 \pm 0.67 \mathrm{~kg} / \mathrm{bird}$ at the end of the fattening.

In the control group, fed with the addition of corn silage, body weight gain did not exceed $69 \pm 2.6 \mathrm{~g} /$ day/bird and appeared when grower II was used (Fig. 2). Compared to the control, forage acidification and alkalization improved body weight gain at every stage of feeding. Maximum BWG was observed in group B, in which birds were fed the finisher ration containing $\mathrm{CaCl}_{2}$ at $240 \mathrm{~g} / 100 \mathrm{~kg}$ of diet. Moreover, in this group an almost perfect negative correlation $(\mathrm{r}=-0.89)$ between the viscosity of the digesta and BWG was noted. 
In group $\mathrm{E}$, where the turkeys received the finisher ration with $\mathrm{NaHCO}_{3}$ at $480 \mathrm{~g} / 100 \mathrm{~kg}$ of diet, BWG was also markedly $(\mathrm{P} \leq 0.05)$ elevated. Under such conditions, however, the correlation between viscosity and $\mathrm{BWG}$ was moderate, with $\mathrm{r}=-0.53$.

The control turkeys demonstrated an anion gap of $17.8 \pm 1.69$ (before the experiment) and 19.86 \pm 2.37 $\mathrm{mEq} / \mathrm{l}$ in the last week of fattening (Fig. 3). In those birds which received an acidic diet, AG was lower, and remained at a similar level. AG values did not exceed $17.5 \pm 2.12 \mathrm{mEq} / 1$ and $18.25 \pm 0.8 \mathrm{mEq} / 1$ in groups $\mathrm{B}$ and $\mathrm{C}$, respectively. The addition of $\mathrm{NaHCO}_{3}$ in the smaller dose led to a minor depletion of $A G$ from $17.83 \pm 1.72$ (before the experiment) to $15.47 \pm 1.73$ $\mathrm{mEq} / \mathrm{l}$ in the $10^{\text {th }}$ week of the experiment. At the same time, the higher dose of $\mathrm{NaHCO}_{3}$ resulted in a marked decrease in $\mathrm{AG}$ to $14.50 \pm 0.90 \mathrm{mEq} / \mathrm{l}$.

In birds which consumed the standard formula with $\mathrm{CS}$ only, the plasma concentration of $\mathrm{HCO}_{3}{ }^{-}$rose systematically from $22.35 \pm 2.24 \mathrm{mEq} / 1$ to $28.46 \pm 0.96$ $\mathrm{mEq} / \mathrm{l}$ (Tab. 4). The exposure of turkeys to both doses of $\mathrm{CaCl}_{2}$ resulted in a gentle decrease in $\mathrm{HCO}_{3}^{-}$. At the end of the experiment, the plasma level of bicarbonates averaged $20.1 \pm 1.04 \mathrm{mEq} / 1$ and $20.25 \pm 0.63$ $\mathrm{mEq} / \mathrm{l}$ in groups $\mathrm{B}$ and $\mathrm{C}$, respectively. Conversely, the addition of $\mathrm{NaHCO}_{3}$ to the diet led to a notable elevation in $\mathrm{HCO}_{3}{ }^{-}$to $29.63 \pm 0.4 \mathrm{mEq} / 1$ in group $\mathrm{D}$ and to $30.3 \pm 0.69 \mathrm{mEq} / 1$ in group $\mathrm{E}$.

Under the experimental conditions, the change in DCAD was combined with improvements in feed intake and body weight gain. These stimulatory responses may have been caused by alterations in gastro-intestinal digestion, acid-base disequilibrium and tissue responses to metabolic hormones $(5,21,27)$.

The clearest indicator of the usefulness of meal supplemented with anionic and cationic salts was the quantity of food consumed. Although both salts considerably enhanced the appetite, the largest food intake was noted in the group receiving rations enriched with anionic salts $\left(\mathrm{CaCl}_{2}\right)$. Moreover, birds that were simultaneously offered rations with CS only and rations supplemented with $\mathrm{CaCl}_{2}$, preferentially consumed the latter. Therefore, it is not surprising that some authors call these salts food intake regulators (29). Data presented by other authors with regard to appetite changes caused by anionic-cationic salts are not uniform. Our results are consistent with earlier reports on stimulatory effects of anionic salts on dry matter intake in cows in relation to the period of exposure (26). On the other hand, these stimulatory responses to anionic salts in our turkeys contrast with the data for broiler chicks provided by Kim et al. (14). However, the possibility that chloride can reduce feed intake exists only in a state of abnormal lysine levels when chloride violates the tissue patterns of basic amino acids, resulting in a decreased appetite. Furthermore, previous reports show that birds fed a diet containing a high level of DEB consumed

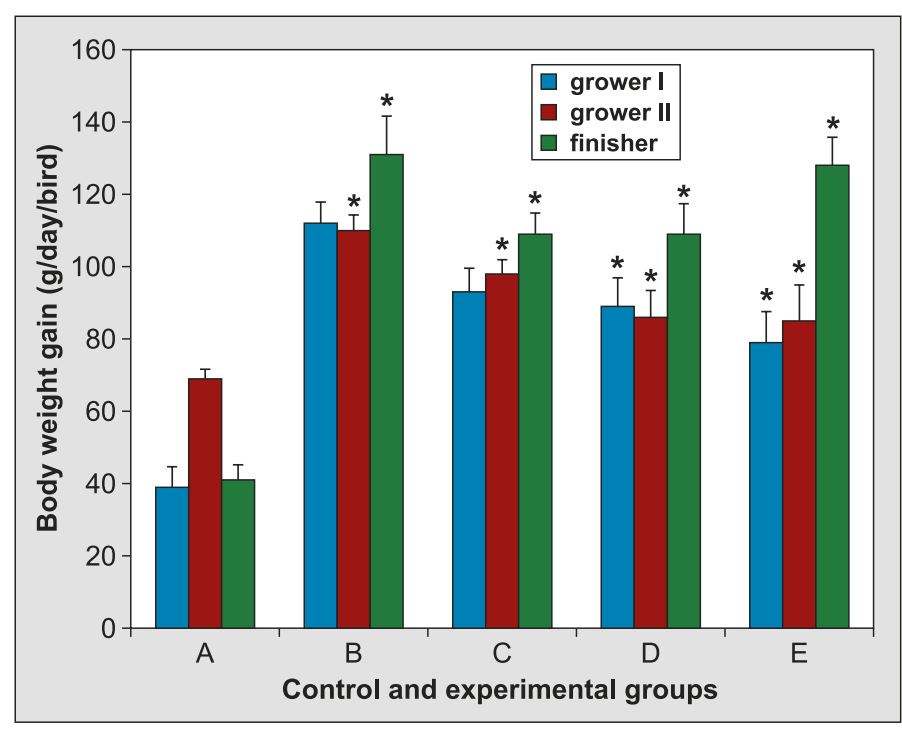

Fig. 2. Influence of different kinds of diet on the body weight gain of turkeys

Explanation: * significant differences $($ at $\mathrm{P} \leq 0.05)$ in comparison to the control group

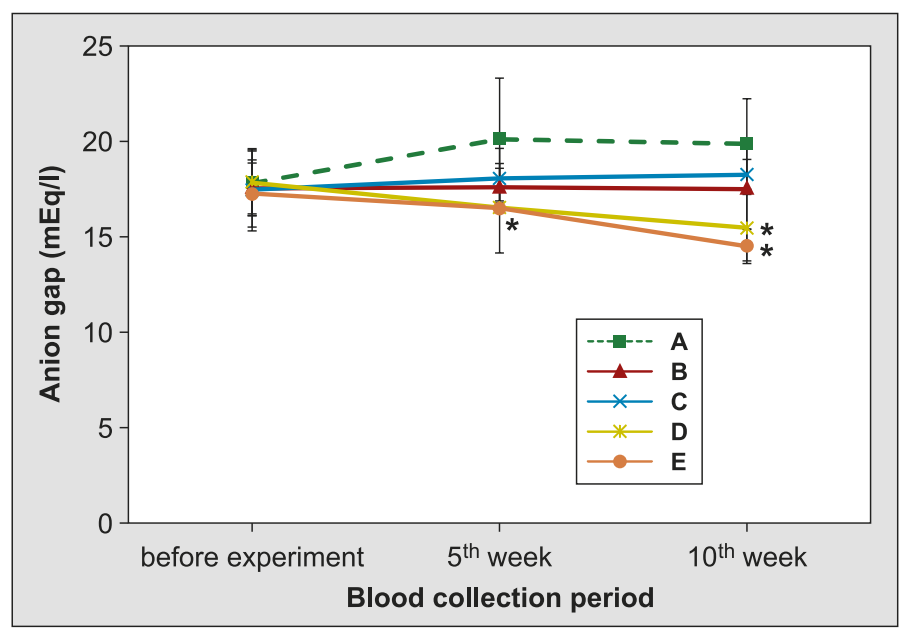

Fig. 3. Response of the anion gap (AG) obtained under different DCAD conditions in control and experimental turkeys Explanation: * significant differences (at $\mathrm{P} \leq 0.05)$ in comparison to the control group

Tab. 4. Plasma concentration of $\mathrm{HCO}_{3}^{-}$in control and experimental groups of turkeys $(n=18, \bar{x} \pm S D)$

\begin{tabular}{|c|c|c|c|}
\hline $\begin{array}{c}\text { Control and } \\
\text { experimental } \\
\text { groups }\end{array}$ & \multicolumn{3}{|c|}{ Blood collection period } \\
\hline before experiment & $5^{\text {th }}$ week & $1^{\text {th }}$ week \\
\hline B & $22.35 \pm 2.24$ & $24.83 \pm 2.55$ & $28.47 \pm 0.96^{*}$ \\
C & $21.43 \pm 0.75$ & $20.15 \pm 0.77$ & $20.10 \pm 1.04$ \\
D & $22.10 \pm 4.02$ & $21.60 \pm 1.55$ & $20.25 \pm 0.63$ \\
E & $22.70 \pm 0.98$ & $25.05 \pm 2.49$ & $29.63 \pm 0.40^{*}$ \\
\hline
\end{tabular}

Explanations: *significant differences (at $\mathrm{P} \leq 0.05$ ) vs. plasma $\mathrm{HCO}_{3}{ }^{-}$obtained before the experiment

less feed $(\mathrm{P}<0.05)$ than did birds on a low-DEB diet (2). Meanwhile, in pigs, an augmented feed intake has been regarded as the sole response stimulated by an oscillation in DCAD $(18,19)$. In this species, more 
acidogenic rations have seemed superior to alkalogenic ones in improving the food intake.

In all of our experimental groups, the mean body weight increased continuously during the 10 weeks of the production period, but was lowest in the group receiving meals with $\mathrm{CS}$ only. For the pure CS diet, BWG was almost a half of that for the CS diets supplemented with acidogenic or alcalogenic diets. The growing responses (BWG) to CS rations supplemented with both salts were most evident in the last phase of growth with the finisher diet. What is interesting, is that the doubling of the anionic salts suppressed BWG in all successive nutrition periods, whereas cationic salts, in the last two phases of growth, enhanced it under the same experimental conditions. The slightly reduced BWG after consumption of greater amounts of anionic salts may be consistent with the previous data, according to which the higher levels of chloride resulted in reduced weight gain and a lower efficiency of feed utilization $(7,8,10)$.

Given the earlier data, the optimal range of DCAD for birds should be $180-300 \mathrm{mEq} / \mathrm{kg} \mathrm{DM}$ (13). The results obtained show that a considerable increase in growth parameters (BWG) is induced in broiler turkeys when $\mathrm{CS}$ rations are supplemented by either $\mathrm{CaCl}_{2}$ or $\mathrm{NaHCO}_{3}$ with the range of DCAD between -170.26 and $+338.97 \mathrm{mEq} / \mathrm{kg}$ DM. Positive growth response under such variations in DCAD may, as mentioned above, be associated with improved nutrient availability and utilization. Furthermore, the results published by Adedokun and Applegate (2014) show that the losses of nitrogen and endogenous amino acids (EAAs) are considerably diminished when birds are fed rations with a lower DCAD. Another possible cause of the rise in $\mathrm{BWG}$ was related to the higher feed conversion ratio (FCR) observed in the earlier phase of growth, as well as the declined viscosity of the digesta, which affects many intestinal parameters, including digestive secretions $(3,9,25)$. When digesta viscosity drops, as observed under the influence of acidifying rations, the availability of nutrients is increased. In response to acid addition by $\mathrm{CaCl}_{2}$, proteolytic activity in the glandular stomach is enhanced. On the other hand, the increased digestibility of alkaline chyme under the influence of $\mathrm{NaHCO}_{3}$, is not related to the increased $\mathrm{pH}$ in the stomach, but rather to the liquefaction of stomach contents and to improved conditions for substrate degradation in the intestine. Similarly, the almost unchanged $\mathrm{pH}$ of digesta in our birds (data not published), despite the supply of either acidified or alkalinized rations, reveals a strong neutralizing response from bile and pancreatointestinal secretions that could additionally increase their degradable potential. Support for this statement comes from the recent studies in fish by Saravanan et al. (22) and in swine by Patience et al. (18) and Patience and Wolynetz (19), according to which an increase in DEB to $800 \mathrm{mEq} / \mathrm{kg}$ unequivocally led to an increased digestibility of DM and protein, and ultimately the entire apparent digestibility coefficient (ADC).

It should be emphasized that the acidogenicity or alkalogenicity of a diet is not simply related to the $\mathrm{pH}$ of the diet and cannot be simply used as an indicator of growth performance. Moreover, in accordance with the modern application of Stewart's physicochemical approach to acid-base balance (ABB), the so-called independent variables (SID - the strong ion difference, $\mathrm{A}_{\text {tot }}$ - total weak acid - mainly proteins, $\mathrm{pCO}_{2}$ ) and, to a lesser extent, dependent variables $\left(\mathrm{pH}, \mathrm{HCO}_{3}^{-}, \mathrm{BE}\right)$ mostly determine the changes in $\left[\mathrm{H}^{+}\right]$concentrations in extracellular fluid. According to these principles, commonly known as a quantitative analysis of acid-base status, variations in individual components only minimally alter $\mathrm{ABB}(6)$ Thus, while $\mathrm{Cl}^{-}$anions increased the following consumption of $\mathrm{CaCl}_{2}$, the simultaneous supplementation of $\mathrm{Ca}^{2+}$ could leave $\mathrm{ABB}$ unchanged.

Blood $\mathrm{pH}$ under prolonged acidogenic diets, both in our studies and elsewhere, is maintained near the lowest physiological range $(7,36-7,38)$, which is called "chronic metabolic acidosis" (CMA) (26). This state of CMA is incomparable with clinical metabolic acidosis (KMA) characterized by the inability to compensate for blood $\left[\mathrm{H}^{+}\right]$concentration perturbations. Under such CMA, some acid-base disequilibrium provokes systemic stress on many hormonal axes implicated in growth. Since, under our experimental conditions, ABB parameters nearly remained within the physiological range, catabolic cortisol responses were rather minimal, since the inductivity of this hormone could only take place under clinical metabolic acidosis. On the other hand, responses from other metabolic hormones could favour increments of turkeys.

Given that in turkeys the somatotropic axis with IGF-1 is not only operative, but sharply increases at 1 week of age, it is possible that this proliferative effector system is involved in the DEB-induced improvement in growth rate (16). The same author observes that plasma growth hormone $(\mathrm{GH})$ in broilers reaches its peak at 4 weeks of age, exactly the age at which we started to introduce the acidogenic or alkaligenic diet. It is thus justified to assume that these supplements support growth responses with the involvement of the somatotropic axis, especially as GH in birds, including turkeys, originates not only from pituitary somatotrophors, but also from peripheral tissues, where it is known that mild acidogenic stress enhances protein synthesis (12).

In conclusion, a change in DCAD during the feeding of forage containing CS exerts stimulatory effects on productive parameters of turkeys. Furthermore, we suggest that the positive growth responses under the influence of changes in DCAD, irrespective of their direction, result from the correction of various kinds of metabolic stresses to which turkeys are exposed in the course of production. 


\section{References}

1. Abbas A., Khan M. J., Naeem M., Ayaz M., Sufyan A., Somro M. H.: Cation anion balance in avian diet: (a review). Agric. Sci. Res. J. 2012, 2, 302-307.

2. Adedokun S. S., Applegate T. J.: Dietary electrolyte balance influences ileal endogenous amino acid losses in broiler chicken. Poult. Sci. 2014, 93, 935-945.

3. Alzawqari M., Kermanshahi H., Nassiri Moghaddam H.: The effect of glycine and desiccated ox bile supplementation on performance, fat digestibility, blood and illeal digesta viscosity of broiler chickens. Global Vet. 2010, 5, 187-194.

4. Bobowiec R., Wójcik M., Martelli F., Tusinska E.: Changes in the anion gap induced by $\mathrm{NH}_{4} \mathrm{Cl}$ and furosemide in rabbits. Med. Weter. 2002, 6, 456-461.

5. Borges S. A., Fischer da Silva A. V., Ariki J., Hooge D. M., Cummings K. R.: Dietary electrolyte balance for broiler chickens exposed to thermoneutral or heat-stress environments. Poult. Sci. 2003, 82, 428-435.

6. Borges S. A., Fischer da Silva A. V., Majorka A.: Acid base balance in broilers. World Poultry Sci. J. 2007, 63, 73-81.

7. Borges S. A., Fischer da Silva A. V., Majorka A., Hooge D. M., Cummings $K$. R.: Physiological responses of broiler chickens to heat stress and dietary electrolyte balance (sodium plus potassium minus chloride, milliequivalents per kilogram). Poult. Sci. 2004, 83, 1551-1558.

8. Farahat M. H., Abdel-Razik W. M., Hassanein E. I., Noll S. L.: Effect of phytase supplementation to diets varying in chloride level on performance, litter moisture, foot pad score, and gait score of growing turkeys. Poult. Sci. 2013, 92, 1837-1847.

9. Foye O. T., Black B. L.: Intestinal adaptation to diet in the young domestic and wild turkey (Meleagris gallopavo). Comp. Biochem. Phys. A. 2006, 143, 184-192.

10. Gous R. M.: Nutritional limitations on growth and development in poultry. Livest. Sci. 2010, 130, 25-32.

11. Günal M.: Performance and some digesta parameters of broiler chickens given low or high viscosity wheat-based diets with or without enzyme supplementation. Turk. J. Vet. Anim. Sci. 2004, 28, 323-327.

12. Harvey S.: Growth hormone and growth? Gen. Comp. Endocr. 2013, 190, 3-9.

13. Johnson R. J., Kurunajeewa H.: The effect of dietary minerals and electrolytes on the growth and physiology of the young chick. J. Nutr. 1985, 115, 1680-1690 .

14. Kim H. W., Han I. K., CHoi Y. J.: Effects of lysine level and $\mathrm{Na}^{+} \mathrm{K}-\mathrm{Cl}$ ratio on lysine-arginine antagonism, blood $\mathrm{pH}$, blood acid-base parameters and growth performance in broiler chicks. Asian Austral. J. Anim. Sci. 1989, 2, $7-16$.
15. Kitowski I., Sujak A., Strobel W., Wiacek D.: Trace elements in eggshells of the Grey Heron (Ardea cinerea) from the colony in the Roztocze Hills (South East Poland) Zool. Ecol. 2013, 23, 240-244.

16. McGuinness M. C., Cogburn L. A.: Measurements of developmental changes in plasma insulin-like growth factor-1 levels of broiler chickens by radioreceptor assay and radioimmunoassay. Gen. Comp. Endocr. 1990, 79, 446-458.

17. Olanrewaju H. A., Thaxton J. P., Dozier W. A., Branton S. L.: Physiology, endocrinology, and reproduction. Electrolyte diets, stress, and acid-base balance in broiler chickens. Poult. Sci. 2007, 86, 1363-1371.

18. Patience J. F., Austic R. E., Boyd R. D.: Effect of dietary electrolyte balance on growth and acid-base status in swine. J. Anim. Sci. 1987, 64, 457-466.

19. Patience J. F., Wolynetz M. S.: Influence of dietary undetermined anion on acid-base status and performance in pigs. J. Nutr. 1990, 120, 579-587.

20. Riond J. L.: Animal nutrition and acid-base balance. European J. Nutr. 2001, 40, 245-254.

21. Robey I. F.: Examining the relationship between diet-induced acidosis and cancer. Nutr. Metab. 2012, 9, 72-78.

22. Saravanan S., Geurden I., Orozco Z. G. A., Kaushik S. J., Verreth J. A. J., Schrama J. W.: Dietary electrolyte balance in fish. Brit. J. Nutr. 2013, 110 1948-1957.

23. Shahbaz T. H., Zafar Alam M., Nadeem A., Ashfag M.: Effect of varying dietary cation-anion balance on broilers growth. Pak. J. Lif. Soc. Sci. 2004, 2, 82-84.

24. Smits C. H. M., Veldman A., Verstegen M. W. A., Beynen A. C.: Dietary carboxymethylcellulose with high instead of low viscosity reduces macronutrient digestion in broiler chickens. J. Nutr. 1997, 127, 483-487.

25. Stef L., Drinceanu D. R., Carpirta R., Simiz E., Pandur C., Stef D., Julean C., Fota $D$.: Intestinal viscosity at broiler chickens fed with combined forages with different proportions of barley. SPASB 2008, 41, 559-566.

26. Vagnoni D. B., Oetzel G. R.: Effects of dietary catio-anion difference on the acid-base status of dry cows. J. Dairy Sci. 1998, 81, 1643-1652.

27. Veldkamp T., Kwakkel R. P., Ferket P. R., Simson P. C., Noordhuizen J. P. Pijpers $A$. B.: Effect of ambient temperature, arginine-to-lysine ratio, and electrolyte balance on performance, carcass, and blood parameters in commercial male turkeys. Poult. Sci. 2000, 79, 1608-1616.

28. Wójcik M., Martelli F., Bobowiec R., Patkowski K., Chałabis-Mazurek A., Watkuska $G$.: Influence of diet cation-anion difference (DCAD) on plasma acid-base status in pregnant sheep. Med. Weter. 2009, 65, 679-682.

29. Yen I. T., Pond W. G., Prior R. L.: Calcium chloride as a regulator of feed intake and weight gain in pigs. J. Anim. Sci. 1981, 52, 778-778.

Corresponding author: Marta Wójcik DVM, PhD, Akademicka 12, 20-033 Lublin, Poland; e-mail: marta.wojcik@up.lublin.pl 